Bendix-Almgreen \& Peel, this report). In addition, it is probable that the clastic, apparently unfossiliferous sections described already to the east from Nansen Land (Ellitsgaard-Rasmussen, 1955) and northern Peary Land (Dawes \& Soper, 1973), similarily extend into the Devonian.

The suggestion about the presence of Devonian rocks in North Greenland has hitherto been made mainly on the basis of comparisons with the Canadian part of the Franklinian geosyncline where Devonian sediments are well developed (e.g. Kerr, 1967). The present graptolite determinations, together with the vertebrate fauna mentioned below, supply the first faunal evidence to support such an inference.

\title{
References
}

Dawes, P. R. 1971: The North Greenland fold belt and environs. Bull. geol. Soc. Denmark 20, 197-239.

Dawes, P. R. \& Soper, N. J. 1973: Pre-Quaternary history of North Greenland. Mem. Amer. Ass. Petrol. Geol. 19, 117-134.

Ellitsgaard-Rasmussen, K. 1955: Features of the geology of the folding range of Peary Land North Greenland. Meddr Grønland 127, 7, 56 pp.

Kerr, J. W. 1967: Nares submarine rift valley and the relative rotation of North Greenland. Bull. Can. Petrol. Geol. 15, 483-520.

Koch, L. 1920: Stratigraphy of Northwest Greenland. Meddr dansk geol. Foren. 5, 17, 78 pp.

Poulsen, C. 1934: The Silurian faunas of North Greenland. I. The fauna of the Cape Schuchert Formation. Meddr Grønland 72, 2 afd., 1, 46 pp.

W. B. N.B.,

Department of Paleontology,

University of California,

Berkeley,

California 94720,

U.S.A.
A. J. B., Department of Geology, Oregon State University, Corvallis, Oregon 97331 , U.S.A.

\section{EARLY DEVONIAN VERTEBRATES FROM HALL LAND, NORTH GREENLAND}

\author{
Svend Erik Bendix-Almgreen and John S. Peel
}

During investigation of collections from North Greenland made by P. R. Dawes and J. H. Allaart, as part of Operation Grant Land 1965-66, one of the authors (J. S. P.) found vertebrate remains in samples which had been subjected to acetic acid digestion. The vertebrate material was subsequently examined by S. E. B.-A. who found it to comprise thelodonts, heterostracans and acanthodians (illustrated 
in Bendix-Almgreen, in press) suggestive of an approximate late Silurian (Pridoli) - Lower Devonian age. This age is in general agreement with the late Silurian early Devonian date suggested by Berry $e t$ al. (this report) for graptolites from stratigraphically slightly lower beds in the same sequence of strata in western Hall Land. The two age determinations provide the first palaeontological evidence for the presence of late Silurian (Pridoli) and early Devonian strata in the Franklinian geosynclinal sequence of North Greenland.

\section{The material}

GGU collections 82737, 82738. Collected by P. R. Dawes and J. H. Allaart in 1965, $2 \mathrm{~km}$ north-east of Hall's Grav, western Hall Land, at an altitude of about $215 \mathrm{~m}$ on the eastern side of 'Observatory Bluff'. Grey limestones from a $1 \mathrm{~m}$ thick bed of limestone in a sequence of calcareous shales and sandstones. In addition to vertebrate remains, the samples contain an abundant fauna of marine invertebrates including: phosphatised ostracods, internal moulds of bellerophontacean and murchisoniacean gastropods, bryozoans, Heliolites sp. and rare conodonts, cephalopods and brachiopods (articulate and inarticulate).

\section{The vertebrate fauna}

Thelodonts. Among the detached thelodont scales occur types resembling Thelodus trilobatus as figured by Gross (1967, pl. 2, figs 13-21) and 'Thelodus scoticus', the former of which has been recorded from deposits such as the $K_{4}$ beds, Ohesaare Pank (Oesel) now believed to be of upper Downtonian (=Pridoli) age.

Heterostracans. Some of the fragments of plates and scales placed in this group undoubtedly belong to cyathaspids. Their dentine-ridge pattern more closely resembles Poraspis (see e.g. Kiær \& Heintz, 1935) than Anglaspis (Kiær, 1932). Other scale or plate fragments agree even in precise details of shape, size and distribution of their dentine ridges, with those characterising the so-called Oniscolepis (Strosipherus), as described by Gross (1961) on the basis of detached scales and plates from the Ohesaare Formation (upper Downtonian) of Oesel and from erratics of the Beyrichia Limestone found in northern Germany. As emphasised by Ørvig (1969), when evaluating somewhat similar material from the primaeva beds of the Frænkelryggen Formation (regarded as comprising strata of both Downtonian and Dittonian age) of Vestspitsbergen, with our present knowledge it is difficult to decide what such resemblance means. The Greenland specimens are therefore referred to here as Heterostraci inc. sed. Oniscolepis? sp.

Acanthodians. Remains belonging to this group constitute the great majority of the material available from the two samples and comprise detached scales, frag- 
ments of fin-spines and dentigerous jaw-bones, as well as tooth-whorls. All the dentigerous jaw-bone fragments that show diagnostic features appear to belong to the Nostolepis type, i.e. their principal tooth-cusps are more or less triangular in cross-section, a main diagnostic character for this type according to Gross (1957; see also Ørvig, 1967). Scales of the Nostolepis type are also abundant and those features that are shown by the fin-spine fragments make it reasonable to associate some of these also with Nostolepis. The tooth-whorls in the samples, on the other hand, agree with those in 'Gomphodus' (cf. Gross, 1957, pp. 5-6, pls. 1-3) and ischnacanthids; none of them, at any rate, have tooth-cusps of the 'blattförmig' kind which, according to Gross (1957, p. 35, pl. 4, figs 6-7), should be diagnostic for tooth-whorls belonging to Nostolepis. This peculiar circumstance may of course be due only to the small number of remains available for examination before the present preliminary report was written.

\section{Discussion}

The vertebrate fauna so far examined from Hall Land is as presently known decidedly poor when compared to other late Silurian - early Devonian faunas, of which the best known (at least in terms of biostratigraphic comparisons and evaluations) are those from Vestspitsbergen (the primaeva beds of the Frænkelryggen Formation) and from the 'Psammosteus' Limestone Group of the AngloWelsh Borderland (see Ørvig, 1969, for full references). No remains of such important groups as osteostracans and anaspids have so far been found in the Hall Land material while the only heterostracans that could be identified are Poraspis sp. and a form resembling Oniscolepis. The genus Poraspis occurs in strata ranging in age from the Downtonian to the late Gedinnian (Denison, 1964). Concerning the remains referred to above as Heterostraci inc. sed. Oniscolepis? sp., one has at present no means of telling whether or not the resemblance to Oniscolepis remains from the upper Downtonian Ohesaare Formation (Oesel) has any bearings on actual close relationship. None of the heterostracans are therefore of much significance for biostratigraphic correlation, or for closer age determination of the Hall Land deposits under consideration. The same applies to those thelodonts and acanthodians so far detected in the material.

The two samples that have so far yielded the vertebrate material described here are derived from strata which are located stratigraphically above beds containing Monograptus sp. of $M$. transgrediens type and Monograptus cf. $M$. aequabilis (Berry et al., this report). These graptolites indicate an early Devonian age for the beds in which they occur. Neither with regard to the general composition of the vertebrate fauna nor with regard to the various vertebrate types detected in it, is there anything to disagree seriously with the age indication offered by the monograptids, for which reasons the new vertebrate fauna from Hall Land is provisionally referred to the early Devonian. 
The Hall Land vertebrates occur at almost the same stratigraphical level as the large and varied vertebrate fauna discovered in recent years in marine beds of the Peel Sound Formation in the Canadian Arctic Archipelago (Thorsteinsson, 1958; 1967; Thorsteinsson \& Tozer, 1963; Broad, 1973; Broad \& Dineley, 1973). The general similarity between Palaeozoic strata in North Greenland and Arctic Canada is well known (e.g. Kerr, 1967) and, with due regard for the close geographical proximity of these faunas, it is tempting to suggest that increasing knowledge of the new early Devonian vertebrate fauna from Greenland will show it to be closely related to, or perhaps even identical with, the fauna from the lower member of the Peel Sound Formation.

\section{References}

Bendix-Almgreen, S. E. in press: The palaeovertebrate faunas of Greenland. In: Escher, A. \& Watt, W. S. (edit.) Geology of Greenland. Copenhagen: Geol. Surv. Greenland.

Broad, D. S. 1973: Amphiaspidiformes (Heterostraci) from the Silurian of the Canadian Arctic Archipelago. Bull. geol. Surv. Can. 222, 35-52.

Broad, D. S. \& Dineley, D. L. 1973: Torpedaspis, a new Upper Silurian and Lower Devonian genus of Cyathaspididae (Ostracodermi) from Arctic Canada. Bull. geol. Surv. Can. 222, 53-92.

Denison, R. H. 1964: The Cyathaspididae. A family of Silurian and Devonian jawless vertebrates. Fieldiana, Geol. 13, 307-473.

Gross, W. 1957: Mundzähne und Hautzähne der Acanthodier und Arthrodiren. Palaeontographica A, 109, 1-40.

Gross, W. 1961: Aufbau des Panzers obersilurischer Heterostraci und Osteostraci Norddeutschlands (Geschiebe) und Oesels. Acta Zool. Stockh. 42, 73-150.

Gross, W. 1967: Über Thelodontier-Schuppen. Palaeontographica A, 127, 1-67.

Kerr, J. W. 1967: Nares submarine rift valley and the relative rotation of North Greenland. Bull. Can. Petrol. Geol. 15, 483-520.

Kiær, J. 1932: The Downtonian and Devonian vertebrates of Spitsbergen. 4. Suborder Cyathaspida. A preliminary report edited by A. Heintz. Skr. Svalbard Ishavet 52, 1-26.

Kiær, J. \& Heintz, A. 1935: The Downtonian and Devonian vertebrates of Spitsbergen. 5. Suborder Cyathaspida. 1. Tribe Poraspidei. Family Poraspidae Kiær. Skr. Svalbard Ishavet 40, 1-138.

Ørvig, T. 1967: Some new acanthodian material from the Lower Devonian of Europe. J. Linn. Soc. (Zool.) 47, 131-153.

Ørvig, T. 1969: The vertebrate fauna of the primaeva Beds of the Frænkelryggen Formation of Vestspitsbergen and its biostratigraphic significance. Lethaia 2, 219-239.

Thorsteinsson, R. 1958: Cornwallis and Little Cornwallis Islands, District of Franklin, Northwest Territories. Mem. geol. Surv. Can. 294, 134 pp.

Thorsteinsson, R. 1967: Preliminary note on Silurian and Devonian ostracoderms from Cornwallis and Somerset Islands, Canadian Arctic Archipelago. Colloques Int. Cent. Natn. Rech. Scient. 163, 45-47.

Thorsteinsson, R. \& Tozer, E. T. 1963: Geology of northern Prince of Wales Island and northwestern Somerset Island. Mem. geol. Surv. Can. 320, 117-129.

S.E. B.-A.,

Mineralogical Museum,

Øster Voldgade 5-7, 1350 Copenhagen $K$. 